Szociológiai Szemle 28(2): 150-154.

\title{
Játszva tanulás - a tér hatása az oktatásra A tanulás helyei: iskolaépítészet
}

\author{
Szerk. Sárkány Péter - Tamáska Máté \\ Martin Opitz Kiadó, Budapest 2017, 140 o.
}

\section{Kovács Bernadett}

https://doi.org/10.51624/SzocSzemle.2018.2.9

Formáljuk a teret és az formál minket, így akarva-akaratlanul is egymásba fonódunk vele. Az épített környezet társadalmi valósága minden történeti korszakban meghatározó volt, és az ma is, a virtuális terek megjelenése idején (Berger 2016: 5-6). $\mathrm{Az}$ építészeti környezet vizsgálata a szociológia számára tehát nem kitekintés más tudományterületek felé, hanem saját tudományterületének szerves része. Illetve az kellene hogy legyen, ám a valóság az, hogy a társadalomtudományi diskurzusban a tér anyagi valósága, tehát az épített környezet, a tényleges szerepéhez képest alulértékelt.

A tér és a társadalom kapcsolatát hagyományosan a településszociológia tárgykörébe szokás sorolni, holott a nemzetközi szakirodalomban létezik a téri valóság dimenziójával intenzívebben foglalkozó szakdiszciplína is: az építészetszociológia. Az építészetszociológiát felfoghatjuk a településszociológia egy szegmensének is, de szerencsésebb attól elkülöníteni, hiszen önálló tárgya van, az épített környezet, illetve önálló módszertana, amely az építészeti formák közvetlen megértését feltételezi. Ez a módszertan az építészettudományhoz hasonló részletességgel tárja fel a térstruktúrákat, a formai párhuzamokat, funkcionális kapcsolatokat, illetve kommunikációs mintázatokat (Farkas 1996: 1).

Magyarországon az építészetszociológia fogalma ma még kevésbé ismert, holott a gyakorlatban, pl. a várostervezésben komoly hagyományai vannak. Ha annak idején nem is építészetszociológiaként definiálták őket, például S. Nagy Katalin (1981) lakáskultúra-kutatásai vagy Kapitány Ágnes és Kapitány Gábor (1989) térszimbolikai vizsgálatai mindenképpen e tárgykörbe sorolhatók. Tamáska Máté, az iskolaépítészeti kötet egyik szerkesztője pedig éppen a Szociológia Szemlében közölte első, kifejezetten építészetszociológiai tematikájú felmérését, melynek elméleti alapvetését Hajnal István történetszociológiai fogalmai adták (Tamáska 2006). Az alább ismertetett kötet egyik szerkesztőjét ismerve tehát korántsem előzmények nélküli, hogy a könyv egyben első darabja egy tervezett építészetszociológiai sorozatnak, amely a hajnali módszertanra utalva a „Térformák - Társadalomformák” címet kapta.

A borítón található gyermekrajz tükrözi gyermeki énünk vágyakozását egy játszó- 
ház jellegú iskola után, s ha játszóházzá nem válik is az iskola, a tanulmányokban felvázolt ötletek egy oldottabb építészeti és oktatási közegről szólnak. A tanulmányokat osztrák, német, belga és magyar szerzők jegyzik, valamennyien az iskolai tér specialistái, képzettségüket tekintve azonban sokfélék: van köztük pedagógus, építész, pszichológus, társadalomtudós. Közös azonban a törekvés, hogy a tudományos kutatások hozzájáruljanak a gyermekek számára élhetőbb környezet megteremtéséhez, ezáltal pedig könnyebb és hatékonyabb legyen a tudás befogadása. A gyakorlati alkalmazás iránti elkötelezettséget a mühelytanulmányok jelzik leginkább, amelyekben egy-egy iskolaépítészeti (felújítási) projektről olvashatunk.

Mind a gyakorlatorientált mühelytanulmányok, mind a hagyományos értelemben vett kutatási tanulmányok közös megállapítása, hogy a mai iskolaépítészet túlságosan kihangsúlyozza a tanárok és a diákok közötti társadalmi távolságot, és nem hagy teret a csoportdinamikai munkának. Ez nem csak a tanár munkáját nehezíti meg, de hozzájárul az iskolai szegregációhoz, az esélyegyenlőtelenségek növekedéséhez. A reformpedagógiai módszerek hiányát sok esetben értetlenül nézik a szakértők, pedig gyakran a tér nem megfelelő kialakítása áll a probléma hátterében. A tanári munkamódszereknek sok esetben ellentmondó térkialakítás miatt sem a pedagógusok, sem a diákok nem tudnak élni az újítások adta lehetőségekkel. A sorba rendezett, jóformán lebetonozott padok megnehezítik a kooperatív munkát, a tanárok tábla előtt rögzített helyzete pedig a tanárok társadalmi távolságát hangsúlyozza.

A kötet bevezetőjében Tamáska Máté két csoportba osztja az iskolaépítészeti kutatásokat. Az egyik csoportba azokat a munkákat sorolja, amelyek belülről, tanulói és tanítói szemüvegen keresztül, tehát a pedagógiai munka felől közelítették meg a témát, majd jutottak el társadalmi kérdésekig. A tanulmányok másik csoportja inkább az iskola társadalmi makrokörnyezetét helyezte elötérbe, és innen jutott el a kis terek problémáiig (9. o.). A tanulmánykötetben mindkét stratégiára találunk példát.

A kis terek felől közelítő egyik írást Christian Rittelmeyer német környezetpszichológus jegyzi. A tanulmányban leírt kutatás főbb eredményeként megemlíthető, hogy a közízlés és az építészeti szakmai ízlés között olykor hatalmas szakadék tátong. A diákok elutasították a díjnyertes, ám monoton kiképzésú épületet, azonban a színes - formáját tekintve a díjnyertes épülettől teljesen eltérő iskola - elnyerte tetszésüket (Rittelmeyer 1994: 90). Érdemes megemlíteni Antje Lehn és Renate Stuefer kiállítási projektjét is. A szerzők az iskolai közösségi tervezés módszereit a tárlaton részt vevő gyermekek feladatmegoldásain keresztül vizsgálták. A téralkotás kétszintű folyamat, melynek egyik szintjén a gyermek érzékeli a teret, alakítani azonban csak egy másik cselekvővel folytatott kommunikáció során tudja. Ezek alapján a tér formálása éppúgy szól a társas viszonyokról, mint a fizikai értelmemben vett formákról (Lehn-Stuefer 2017: 110).

A makroszint felől közelítő írások között említhető Tánczos Tibor munkája, aki a térfelosztás direkt vagy indirekt szimbolikáját feltárva, tervezői, értékközvetítői szemszögből közelít a témához. Különösen érdekes az összefüggés, amely a minden- 
kori munkaszervezeti változások és az iskola térbeli reformjai között kimutatható. A Bielefeldi Laboratóriumiskola például a hetvenes évek osztatlan irodáinak a mintáját követte. Az iskola azonban arra is példa, hogy nem elég csak a teret megváltoztatni, de hozzá kell igazítani az oktatási módszereket is. A kettő harmóniája hozhat kiemelkedő eredményeket (Tánczos 2017: 42).

Franz Hammerer - Tánczos Tiborhoz hasonlóan - szintén a társadalmi környezet és az iskola kapcsolatát helyezi elótérbe. Hangsúlyozza az iskola meghatározó szocializációs jellegét, ahol is kifejlődik a diákok egymás iránti tisztelete, az empátiakészség, és mintákat kapnak a társadalomi szerepek betöltéséhez is, megtanulják a demokrácia szabályait (Hammerer 2017: 68). Ő fogalmazza meg talán legélesebben azt az ellentmondást, hogy miközben az európai társadalom a 19. század vége óta alapvető változáson ment keresztül, az osztálytermek szinte semmit sem változtak, megtartották akkoriban kialakult alapstruktúrájukat. Az iskolai tér változatlansága annál is inkább meglepő, mert a fizikai környezet hatása az oktatási munka menetére jól ismert tény a neveléstudományi munkákban. A színek, a természetes fény, a berendezések és a természetes anyagok mind inspirálóan, pozitívan hatnak a gyermekekre. Ennek ellenére az oktatási folyamatot a legtöbb esetben a tanár-diák viszony szerint szemléljük, kihagyva az iskola épületét. Márpedig az épület fizikai valóságában olyan - sokszor ki nem mondott - társadalmi értékeket és elvárásokat közvetít, amelyekhez mind a tanító, mind pedig a diák alkalmazkodik (Tutenel-Crooevits 2017: 20). Az iskola térbeli elrendezése empirikusan igazolható módon hat a teret használó diákok és tanárok hangulatára, befogadóképességére, továbbá a társas kapcsolatok alakulására.

A fizikai környezet jelentőségének a felismeréséhez tudományos előzményként tartozik a hetvenes évektől a társadalomtudományok több területén is lejátszódó „téri fordulat (spatial turn)". E viszonylag közismert jelenségen túl Katharina Rosenberger tanulmánya a „practice turn” néven emlegetett paradigmaváltására is utal, amelynek lényege, hogy a beszéden kívül „a cselekvés teljes fizikai, illetve testi jelenvalóságát figyelembe kell venni” (Rosenberger 2017: 101). Sőt időközben a „body and material cult turn” fogalma is megjelent, amely szerint „az emberi test és az általa használt, illetve az ôt körbe vevő tárgyak egyaránt aktív alkotói a konkrét cselekvési helyzetnek" (Rosenberger 2017: uo.). Ezen a ponton érünk vissza a kötet építészetszociológiai törekvésének lényegéhez, amelyben tehát az iskola építészeti környezete nem csupán háttere a benne folyó munkának, hanem annak cselekvő résztvevője is.

A kötet azonban - noha figyelemre méltó elméleti felvetéseket tesz - elsősorban mégiscsak az iskoláról szól, és kevésbé az építészetszociológia elméleti megközelítéseiről. A 21. századi iskola kérdését tárgyalja, a mai kihívásokra kíván - néha talán túlságosan is normatív - válaszokat adni. A hagyományos folyosós-cellás „fegyelmező" teret felváltó klaszter (vagy tanulóház) modell az egyik ilyen, a bécsi kutatásokban különösen nagyra értékelt térelrendezés. „A klaszter négy osztályteremből, egy úgynevezett piactérből, egy szabadtéri osztályteremből, egy teraszból és egy tanári szobából áll. Az üvegfronton keresztül az egyes zónák vizuálisan összekapcsolódnak" (Hammerer 2017: 
59). Ebben a koncepcióban az iskolaépület bármely területe alkalmas a tanulásra, s így nyitottabb, rugalmasabb személyiségú gyermekek kerülhetnek ki az iskolából, ellentétben azokkal a zárt osztálytermekben szocializálódó diákokkal, akik ezáltal sokkal zárkózottabbá válhatnak (Hammerer uo.).

A klaszterkoncepció tehát bizonyos tekintetben pozitív utópia, amely jobb terektől jobb iskolai munkát, illetve végső soron jobb társadalmat remél. Azonban - amire Tutenel és Coorevits rávilágítanak (2017: 25) - a jó iskola egyben társadalmi verseny is, és a mai elit iskolák (nyugaton) versengenek a térkínálat bővítésében, flexibilitásában, barátságosságában, olyan értékeket állítva előtérbe, melyeket a középosztálybeli szülők gyerekei otthonról hoznak.

A kötet nagy erénye, hogy rávilágít a társadalmi jelenségek, jelen esetben az iskolában folyó munka térbeli meghatározottságára. Felhívja a figyelmet az oktatásszociológiai kutatások rejtett tartalékaira, az iskolaépületek szociológiai vizsgálatának lehetőségeire. Nem utolsósorban a kötet általában hozzájárulhat a hazai építészetszociológiai diskurzus megteremtéséhez.

\section{Irodalom}

Berger V. (2016): A tér kategóriája a szociológia- és társadalomelméletekben. Budapest: ELTE Társadalomtudományi Kar.

Farkas J. (1996): Épitészet-, település- és városszociológia. Budapest: BME Szociológia Tanszék.

Kapitány Á. - Kapitány G. (1989): Intézménymimika. Budapest: VITA.

S. Nagy K. (1981): Lakásmód, lakáskultúra Telkibányán, 1975-1978. Budapest: Népmüvelési Propaganda Iroda.

Tamáska M. (2006): Hagyományos és modern falusi lakóházak örökségszociológiai vizsgálata. Szociológiai Szemle, 4: 36-62.

\section{A kötet recenzióban hivatkozott tanulmányai:}

Hammerer, F. (2017): Az iskolai terekről másként. In Sárkány P. - Tamáska M. (szerk.): A tanulás helyei: iskolaépítészet. Budapest: Martin Opitz Kiadó, 55-71.

Lehn, A. - Stuefer, R. (2017): Ha a tér szilárd alapot ad, a lelkem szárnyalni kezd: egy kiállítás margójára. In Sárkány P. - Tamáska M. (szerk.): A tanulás helyei: iskolaépitészet. Budapest: Martin Opitz Kiadó, 109-120.

Lobrek, M. (2017): Régi terek új lehetőségei: az iskolafelújítások. In Sárkány P. - Tamáska M. (szerk.): A tanulás helyei: iskolaépítészet. Budapest: Martin Opitz Kiadó, 71-86.

Rittelmeyer, Ch. (2017): Az iskolaépítészet hatása a diákokra: nemzetközi kitekintés. In Sárkány P. - Tamáska M. (szerk.): A tanulás helyei: iskolaépitészet. Budapest: Martin Opitz Kiadó, 87-96. 
Rosenberger, K. (2017): Iskolabútorok hatása az oktatásra: alkalmazott kutatásmódszertan. In Sárkány P. - Tamáska M. (szerk.): A tanulás helyei: iskolaépítészet. Budapest: Martin Opitz Kiadó, 97-108.

Tamáska M. (2017): A tanulás helyei: társadalom és iskolaépítészet. In Sárkány P. - Tamáska M. (szerk.): A tanulás helyei: iskolaépitészet. Budapest: Martin Opitz Kiadó, 9-13.

Tutenel, P. - Coorevits, S. (2017): Nem csupán egy tégla a falban: a tanító tér. In Sárkány P. - Tamáska M. (szerk.): A tanulás helyei: iskolaépitészet. Budapest: Martin Opitz Kiadó, 15-32. 